\title{
CAPMH: development of the first open access journal in the field of child mental health
}

Andreas Witt ${ }^{*}$, Gerrit van Schalkwyk ${ }^{2}$ and Jörg M. Fegert ${ }^{1}$

Child and Adolescent Psychiatry and Mental Health (CAPMH) was founded in 2007, an initiative of Prof. Fegert. He served as the Editor-in-Chief, with support from Dr. Benedetto Vitiello (Italy) as Deputy Editor-inChief and Prof. Goldbeck (Germany) and Jacinta Tan (UK) as Associate Editors. The journal was the first independent, open access, online journal in the field with the mission to provide an international platform for rapid and comprehensive scientific communication on child and adolescent mental health issues from diverse cultures and contexts.

The first issue of CAPMH was released in 2007. In February 2013, CAPMH became the official journal of the International Association for Child and Adolescent Psychiatry and Allied Professions (IACAPAP) and has later also been affiliated with the European Association for Forensic Child and Adolescent Psychiatry, Psychology and other involved Professions (EFCAP). Since its inception, the journal has grown rapidly and has received funding by different foundations. However, the journal also faced difficulties and setbacks as sadly, Prof. Goldbeck, one of the founding editors, unexpectedly passed away in 2017.

To further establish the journal in the field of child mental health, the editorial work assertively to establish an impact factor. CAPMH was under consideration to receive an impact factor in 2009 and 2011. Finally, an impact factor was received in 2015. The current impact factor for 2020 is 3.033-a remarkable achievement given

*Correspondence: Andreas.witt@uniklinik-ulm.de

1 Department of Child and Adolescent Psychiatry and Psychotherapy,

University of Ulm, Steinhövelstr. 1, 89075 UIm, Germany

Full list of author information is available at the end of the article the young age and broad mission of the journal. With the new impact factor, the journal has climbed up to rank 37 in Pediatrics, ranks 91 in Psychiatry (Science Citation Index Expanded, SCIE) and remains at rank 66 in Psychiatry (Social Science Citation Index, SSCI), underlining the importance of the journal in the field of child mental health.

The growth of the journal is also reflected in the number of submissions received. Most notably, a dramatic increase in submissions was observed after the journal was awarded an impact factor. Another indicator for the success of the journal is the number of downloads of published articles. With now almost 8,00,000 downloads per year, scholars and practitioners publishing within the journal reach a vast readership worldwide.

Since its foundation the aim of the journal has been to increase the knowledge base related to the diagnosis, prognosis and treatment of mental health conditions in children and adolescents, and to integrate basic science, clinical research and the practical implementation of research findings [1]. Further, the journal offers a platform for reporting factors and mechanisms that help children and adolescents to maintain their mental health. As such, the journal is a rich venue for a multidisciplinary audience; this includes psychiatrists, pediatricians, psychologists, neuroscientists, and allied disciplines.

One outstanding attribute of CAPMH as the first worldwide open access journal in the field of child and adolescent psychiatry, is its international focus. This is reflected by the international editorial board, submissions, publications, and accesses from all over the world. Thematic series focusing on child and adolescent psychiatry in Africa [2] and Asia [3] underline this international focus. The editors particularly encourage authors from original author(s) and the source, provide a link to the Creative Commons licence, and indicate if changes were made. The images or other third party material in this article are included in the article's Creative Commons licence, unless indicated otherwise in a credit line to the material. If material is not included in the article's Creative Commons licence and your intended use is not permitted by statutory regulation or exceeds the permitted use, you will need to obtain permission directly from the copyright holder. To view a copy of this licence, visit http://creativecommons.org/licenses/by/4.0/. The Creative Commons Public Domain Dedication waiver (http://creativecommons.org/publicdomain/zero/1.0/) applies to the data made available in this article, unless otherwise stated in a credit line to the data. 
countries less represented in the child and adolescent psychiatry literature to submit their work.

Besides the publication of incoming manuscripts, CAPMH has focused on specific topics in child and adolescent psychiatry throughout the years. The latest thematic series focuses on the impact of the Covid-19 pandemic [4] and is currently still accepting manuscripts. Prior thematic series focused on forensic child and adolescent psychiatry and mental health [5-8], Non-suicidal self-injury [9-11], child abuse and neglect [12], e-Learning [13], identity [14], early interventions [15] and psychopharmacology [16].

The success of the journal would not have been possible without the work of the committed editors, the editorial board and reviewers. In November 2021 the journal has undergone a new transition as Prof. Fegert stepped down as from his role as Editor-in-Chief and Dr. van Schalkwyk and Dr. Witt have assumed the role together. The new Editors-in-Chief want to express their deep gratitude to the founding editors of Child and Adolescent Psychiatry and Mental Health, who laid the foundation for this exciting project. They want to especially thank Prof. Fegert who has led and shaped the journal since its foundation in 2007. With his work he profoundly contributed to the reach and success of the journal and as the founding editor he stays associated with the editorial team Their thanks also go out to all editors who have been and are currently working with the journal, as well as the editorial board and the vast number of reviewers who have supported the journal throughout the years.

The aim of the new Editors-in-Chief over the next years to come is a continuation of the excellent work of Child and Adolescent Psychiatry and Mental Health and to further advance the impact of the journal in the field. As the flagship journal of the International Association of Child and Adolescent Psychiatry and Allied Professions (IACAPAP) the Editors-in-Chief seek to provide a scientific platform for high quality research and practice in this area by ensuring a rigorous and timely review process. To ensure a timely and quality review process, the aim is to build a reliable and committed board of reviewers that form a relationship with the journal. To further increase the impact of the journal in the field, the aim is to establish thematic series on a regular basis. Such thematic series can address pressing issues of the time and be edited by guest experts or by editors of the journal.

As an international journal for the area of child and adolescent psychiatry and mental health, the vision of the new Editors-in-Chief is to create an international scientific platform that addresses all professions in mental health. As the journal should reflect this international focus, the aim is to increase diversity among the editorial board not only in regards to gender and ethnicity, but also concerning professional backgrounds, methodological and scientific orientation. Therefore, the aim of CAPMH is to attract researchers from all over the world to submit their work to the journal not only from developed countries but also to support high quality work from less developed countries to further advance science and practice in the field of child and adolescent psychiatry and mental health.

\section{Acknowledgements \\ The authors want to thank all editors who have been and are currently work- ing with the journal, as well as the editorial board and the vast number of reviewers who have supported the journal throughout the years.}

\section{Authors' contributions}

AW has drafted the manuscript. All authors read and approved the final manuscript

\section{Funding}

Not applicable.

Availability of data and materials

Not applicable.

\section{Declarations}

Ethics approval and consent to participate

Not applicable.

\section{Consent for publication}

Not applicable.

\section{Competing interests}

AW and GvS are the current Editors-in-Chief of CAPMH. JMF is the former Editor-in-Chief and founding editor of the journal.

\section{Author details}

${ }^{1}$ Department of Child and Adolescent Psychiatry and Psychotherapy, University of UIm, Steinhövelstr. 1, 89075 UIm, Germany. ${ }^{2}$ Department of Pediatrics, University of Utah, Salt Lake City, USA.

Received: 25 November 2021 Accepted: 25 November 2021

Published online: 30 November 2021

\section{References}

1. Fegert JM, Vitiello B. Child and adolescent psychiatry and mental health-development of a new open-access journal. Child Adolesc Psychiatry Ment Health. 2008. https://doi.org/10.1186/1753-2000-2-22.

2. Omigbodun $\bigcirc \bigcirc$, Belfer ML. Building research capacity for child and adolescent mental health in Africa. Child Adolesc Psychiatry Ment Health. 2016;10:27. https://doi.org/10.1186/s13034-016-0119-2.

3. Lim CG, Vitiello B. Child psychiatry services in Asia: evolving state of affairs? Child Adolesc Psychiatry Ment Health. 2015;9:12. https://doi.org/ 10.1186/s13034-015-0044-9.

4. Witt A, Ordóñez A, Martin A, et al. Child and adolescent mental health service provision and research during the Covid-19 pandemic: challenges, opportunities, and a call for submissions. Child Adolesc Psychiatry Ment Health. 2020;14:19. https://doi.org/10.1186/s13034-020-00324-8.

5. Schmeck K, Fegert JM, Boonmann C. Longitudinal studies in forensic child and adolescent psychiatry and mental health: CAPMH thematic series 2018/2019. Child Adolesc Psychiatry Ment Health. 2019;13:20. https://doi.org/10.1186/s13034-019-0280-5.

6. Boonmann C, Fegert JM, Schmeck K. Thematic series CAPMH "Forensic Child and Adolescent Psychiatry and Mental Health 2017." Child 
Adolesc Psychiatry Ment Health. 2018;12:7. https://doi.org/10.1186/ s13034-018-0213-8.

7. Schmeck K, Boonmann C, Fegert JM. Thematic series CAPMH "Forensic Child and Adolescent Psychiatry and Mental Health." Child Adolesc Psychiatry Ment Health. 2016;10:41. https://doi.org/10.1186/ s13034-016-0126-3.

8. Doreleijers TA, Fegert JM. Forensic child and adolescent psychiatry and mental health in Europe. Child Adolesc Psychiatry Ment Health. 2011;5:20. https://doi.org/10.1186/1753-2000-5-20.

9. Brown RC, Witt A. Social factors associated with non-suicidal self-injury (NSSI). Child Adolesc Psychiatry Ment Health. 2019;13:23. https://doi.org/ 10.1186/s13034-019-0284-1.

10. Plener PL, Fegert JM. Nonsuicidal self-injury: a condition for further study. Child Adolesc Psychiatry Ment Health. 2015;9:30. https://doi.org/10.1186/ s13034-015-0067-2.

11. Plener PL, Fegert JM. Non-suicidal self-injury: state of the art perspective of a proposed new syndrome for DSM V. Child Adolesc Psychiatry Ment Health. 2012;6:9. https://doi.org/10.1186/1753-2000-6-9.

12. Fegert JM, Stötzel M. Child protection: a universal concern and a permanent challenge in the field of child and adolescent mental health. Child Adolesc Psychiatry Ment Health. 2016;10:18. https://doi.org/10.1186/ s13034-016-0106-7.

13. Rey JM, Omigbodun OO. International dissemination of evidence-based practice, open access and the IACAPAP textbook of child and adolescent mental health. Child Adolesc Psychiatry Ment Health. 2015;9:51. https:// doi.org/10.1186/s13034-015-0084-1.

14. Schmeck K, Fegert JM, Schlüter-Müller S. On identity. Child Adolesc Psychiatry Ment Health. 2013;7:24. https://doi.org/10.1186/1753-2000-7-24.

15. Fegert $\mathrm{JM}$, Ziegenhain $\mathrm{U}$. Early intervention: bridging the gap between practice and academia. Child Adolesc Psychiatry Ment Health. 2009;3:23. https://doi.org/10.1186/1753-2000-3-23.

16. Fegert JM. Special section on psychopharmacology trials in children and adolescents. Child Adolesc Psychiatry Ment Health. 2008;2:35. https://doi. org/10.1186/1753-2000-2-35.

\section{Publisher's Note}

Springer Nature remains neutral with regard to jurisdictional claims in published maps and institutional affiliations.

Ready to submit your research? Choose BMC and benefit from:

- fast, convenient online submission

- thorough peer review by experienced researchers in your field

- rapid publication on acceptance

- support for research data, including large and complex data types

- gold Open Access which fosters wider collaboration and increased citations

- maximum visibility for your research: over $100 \mathrm{M}$ website views per year

At $\mathrm{BMC}$, research is always in progress.

Learn more biomedcentral.com/submissions 